\title{
Direct Chemical Oxidation: A Non-Thermal Technology for the Destruction of Organic Wastes
}

\author{
G.B. Balazs \\ J.F. Cooper \\ P.R. Lewis \\ M.G. Adamson
}

February 1998

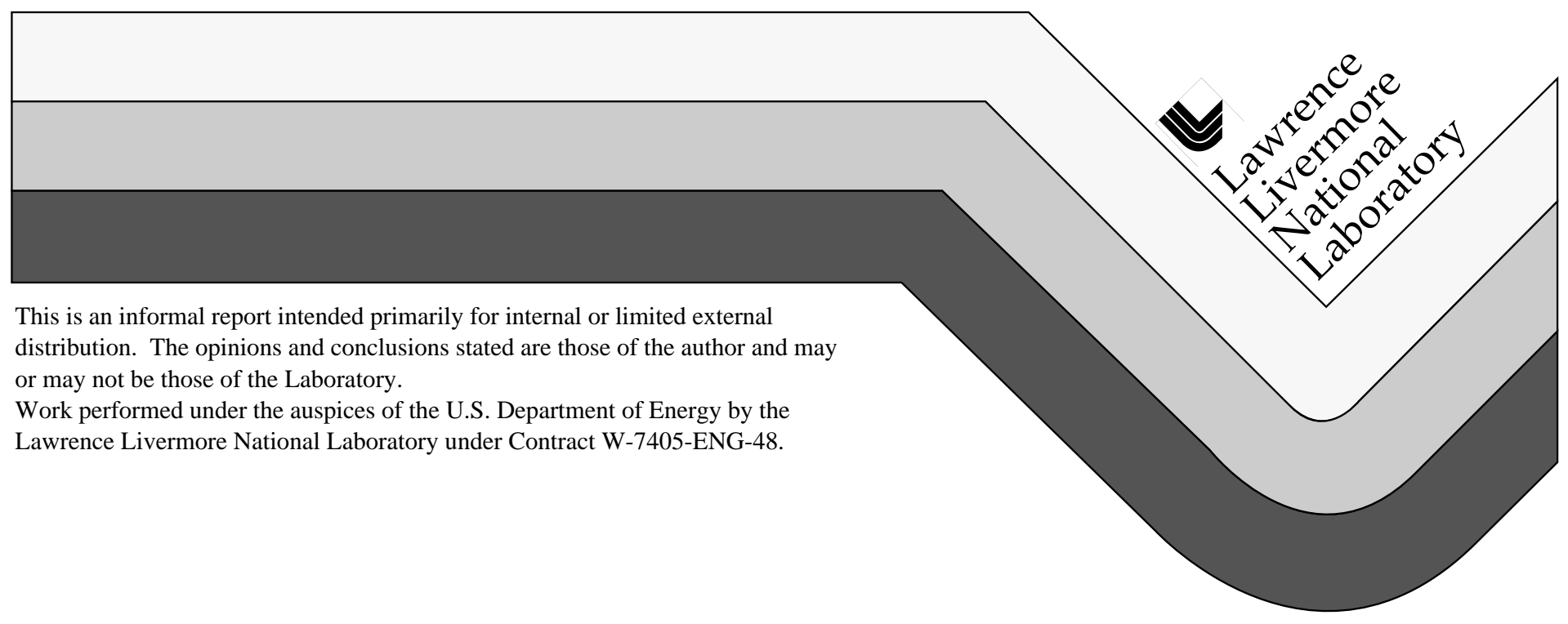




\section{DISCLAIMER}

This document was prepared as an account of work sponsored by an agency of the United States Government. Neither the United States Government nor the University of California nor any of their employees, makes any warranty, express or implied, or assumes any legal liability or responsibility for the accuracy, completeness, or usefulness of any information, apparatus, product, or process disclosed, or represents that its use would not infringe privately owned rights. Reference herein to any specific commercial product, process, or service by trade name, trademark, manufacturer, or otherwise, does not necessarily constitute or imply its endorsement, recommendation, or favoring by the United States Government or the University of California. The views and opinions of authors expressed herein do not necessarily state or reflect those of the United States Government or the University of California, and shall not be used for advertising or product endorsement purposes.

This report has been reproduced directly from the best available copy.

Available to DOE and DOE contractors from the Office of Scientific and Technical Information P.O. Box 62, Oak Ridge, TN 37831

Prices available from (423) 576-8401

Available to the public from the National Technical Information Service

U.S. Department of Commerce 5285 Port Royal Rd. Springfield, VA 22161 
FY98 Final Report

(Addendum to FY97 Report)

Direct Chemical Oxidation:

A Non-thermal Technology for the Destruction of Organic Wastes

G. Bryan Balazs, John F. Cooper, Patricia R. Lewis, Martyn G. Adamson

Lawrence Livermore National Laboratory

Livermore, CA 94550

February 1998 



\section{INTRODUCTION}

\section{A. Summary}

Direct Chemical Oxidation (DCO) is a non-thermal, ambient pressure, aqueous-based technology for the oxidative destruction of the organic components of hazardous or mixed waste streams. The process has been developed for applications in waste treatment and chemical demilitarization and decontamination at LLNL since 1992, and is applicable to the destruction of virtually all solid or liquid organics, including: chlorosolvents, oils and greases, detergents, organic-contaminated soils or sludges, explosives, chemical and biological warfare agents, and PCB's. [1-15] The process normally operates at $80-100{ }^{\circ} \mathrm{C}$, a heating requirement which increases the difficulty of surface decontamination of large objects or, for example, treatment of a wide area contaminated soil site. The driver for DCO work in FY98 was thus to investigate the use of catalysts to demonstrate the effectiveness of the technology for organics destruction at temperatures closer to ambient. In addition, DCO is at a sufficiently mature stage of development that technology transfer to a commercial entity was a logical next step, and was thus included in FY98 tasks.

\section{B. Oxidation Chemistry}

The process uses solutions of the peroxydisulfate ion (typically sodium or ammonium salts) to completely mineralize the organics to carbon dioxide and water. The net waste treatment reaction is (Eq. 1):

$$
\mathrm{S}_{2} \mathrm{O}_{8}{ }^{2-}+\{\text { organics }\} \Rightarrow 2 \mathrm{HSO}_{4}^{-}+\left\{\mathrm{CO}_{2}, \mathrm{H}_{2} \mathrm{O} \text {, inorganic residues }\right\}
$$

Peroxydisulfate is one of the strongest chemical oxidants known (oxidation potential is $+2.05 \mathrm{~V}$ ), and is exceeded in oxidative power only by fluorine, ozone, and oxyfluorides. The oxidation potential of peroxydisulfate is high enough to oxidize nearly any organic substance. [16-17]

While many oxidants exhibit a redox potential capable of broad-spectrum organic oxidation, peroxydisulfate uniquely combines a high oxidation potential with a rapid, nucleophilic charge-transfer capability. Oxidation occurs principally through the formation of the sulfate radical anion $\mathrm{SO}_{4} \bullet$, following mild thermal $\left(70-100{ }^{\circ} \mathrm{C}\right)$ or $\mathrm{UV}$ activation of peroxydisulfate solutions [18-24]:

$$
\mathrm{S}_{2} \mathrm{O}_{8}{ }^{2-} \Rightarrow 2 \mathrm{SO}_{4} \bullet
$$

Alternatively, this radical-generation process may be accelerated at near ambient temperatures (20$50{ }^{\circ} \mathrm{C}$ ) through the use of a catalyst such as metallic platinum, or with dissolved silver, iron, or copper ion catalysts. [see Section III of this report]

The subsequent reaction of the sulfate free radial with the organic and with water results in a cascade of active oxidants including organic free radical fragments and hydroxyl free radicals. The decomposition of peroxydisulfate produces a number of intermediate oxidizers including peroxymonosulfate (a strong industrial bleach), hydrogen peroxide, and nascent oxygen.

The oxidant ammonium or sodium peroxydisulfate is sufficiently stable at or slightly below room temperature to be stored almost indefinitely as a solid or a wet slurry for months. This being the case, the process of waste destruction can be decoupled in time and place from the generation of the peroxydisulfate oxidant. The oxidant becomes reactive only at elevated temperatures or through contact with the catalysts described above. This allows the oxidant to be slowly produced and stockpiled for use in intermittent waste treatment campaigns of short duration.

The exact composition of the offgas stream will depend on the particular waste stream being processed, but several general predictions can be made. Common to all organic waste streams will be carbon dioxide; oxygen will also be produced from the direct oxidation of water by peroxydisulfate (occurring at a slower rate than oxidation of organics). Chlorine will be present in the offgas if chloro-organics are treated in an acidic DCO system. Alternatively, the use of DCO in a basic solution avoids the formation of chlorine, as the chlorine released from the destruction of 


\section{DCO FY98 Final Report, Balazs et al.}

the organic remains as chloride ion in solution. [20,21] If the oxidant is recycled by electrolysis, then oxygen, ozone, and possibly chlorine (if chloride ion is present) will be added to the offgas stream at the anode of the regeneration cell.

\section{Expended Oxidant}

The expended oxidant may be electrolytically regenerated to minimize secondary waste. The ammonium (or sodium) hydrogen sulfate produced as a byproduct of the organic waste oxidation process is relatively non-hazardous, and may be encapsulated in a subsequent inorganic treatment step, or recycled in a flowing electrolyte cell. If recycled, an industrial cell is used which employs a platinum or glassy carbon anode, an inert graphite cathode, and a porous ceramic separator to prevent cathodic reduction of the product. The anodic reaction is (Eq. 3):

$$
2 \mathrm{NH}_{4} \mathrm{HSO}_{4} \Rightarrow\left(\mathrm{NH}_{4}\right)_{2} \mathrm{~S}_{2} \mathrm{O}_{8}+2 \mathrm{H}^{+}+2 \mathrm{e}^{-} \quad \text { (anode) }
$$

while the cathodic half reaction is the reduction of water to form hydrogen gas. [26-28] For such cells, this gas is best immediately oxidized to water (in a catalyzed bed), and the water internally recycled. Commercial catalysts are available and used for this purpose. In specialized applications where the production of hydrogen gas is not desirable (such as in a confined space), the cathodic reaction can be replaced with oxygen reduction using a porous gas diffusion electrode. This modification also reduces the cell voltage by 1 volt (about $20 \%$ ).

\section{Organics Destruction Throughput and Cost Estimates}

Based on our measured as well as literature-tabulated rate constants, the destruction of organic material is nearly independent of the particular compound. [4,18,22,23] Within a factor of two, the oxidation proceeds at a rate of $\sim 200 \mathrm{~kg}$ carbon content $/ \mathrm{m}^{3} / \mathrm{day}$, where $\mathrm{m}^{3}$ is the volume of the chemical oxidation reactor. [4] See Table I. This throughput figure takes into consideration the fall-off in oxidant concentration as the organic material is oxidized in the reactor.

Table I. Selected oxidation rates of typical surrogate wastes by DCO at $80-90{ }^{\circ} \mathrm{C}$

\begin{tabular}{|c|c|c|c|}
\hline $\begin{array}{c}\text { Organic } \\
\text { Substrate }\end{array}$ & $\begin{array}{c}\text { Operation } \\
\text { Mode }\end{array}$ & $\begin{array}{c}\text { Destruction rate } \\
\mathrm{kg} / \mathrm{m}^{3}-\mathrm{day}\end{array}$ & $\begin{array}{c}\text { Extent per pass } \\
\%\end{array}$ \\
\hline Kerosene & Batch Reactor & 186 & $>99.97$ \\
\hline Triethylamine & Batch Reactor & 205 & $>98.8$ \\
\hline $2,4,6-T N T$ & Batch Reactor & 760 & $>99.9$ \\
\hline Dowex & Batch Reactor & 132 & $>99$ \\
\hline Ethylene Glycol & Packed bed Reactor & 432 & $>99.93$ \\
\hline
\end{tabular}

In addition, a wealth of kinetic data has been collected by this group (4,13-15) and other researchers (18-24) on the kinetics of oxidation of numerous organic and inorganic substrates. Integral rate constants for mineralization of organics were clustered about $\mathrm{k}_{\mathrm{a}}=0.01 \mathrm{~min}^{-1}$, and falling within a factor of two of this value, for such diverse substances as oxalic acid, nitromethane, Na-salicylate, formic acid, triethylamine, dimethylsulfoxide, EDTA, 2,2thiodiethanol, sucrose, acetic acid, formamide, 1,4-dioxane, 4-chloropyridine $\mathrm{HCl}$, and sodium lauryl sulfate. The NIST database provides an excellent summary of reaction rates of peroxydisulfate with over 300 selected organic and inorganic materials. [22]

\section{E. Transition Metal Catalysts}

Available literature data includes the catalysis of peroxydisulfate oxidation of organics by a number of transition metal catalysts. [18-20,29-34] These catalyst include the ions of $\mathrm{Cu}$ [2931,34], Ag [18-20,32-34] and Fe [34]. In addition, a number of organic substrates were studied, including alcohols, aldehydes, and ethers. In general, the catalysts act to accelerate the decomposition of peroxydisulfate into the sulfate free radical anion (Eq. 2 above) which leads to a higher rate of organic oxidation by this aggressive oxidant. 
In general, a generalized rate equation applicable to all combinations of catalyst, organic substrate, and oxidant concentrations is not available. In addition, the actual mechanism is often dependent on the particular catalyst, making a universal statement about transition metal catalysis impossible. For example, Fe(III) appears to accelerate some reactions while inhibiting others. However, it was noted that the rate equation for the reduction of peroxydisulfate (Eq. 1 above) follows the general form (Eq. 4):

$$
\mathrm{d}\left[\mathrm{S}_{2} \mathrm{O}_{8}^{2-}\right] / \mathrm{dr}=-\mathrm{k}\left[\mathrm{S}_{2} \mathrm{O}_{8}{ }^{2-}\right]^{\mathrm{x}}[\text { catalyst }]^{\mathrm{y}}
$$

where $\mathrm{x}$ is some value between $1 / 2$ and $3 / 2$ and $\mathrm{y}$ is some value between 0 and $3 / 2$. Note that this rate equation is independent of the organic concentration, i.e., the rate of organic oxidation is limited only by the rate of the formation of the sulfate free radical anion (assuming no mass transport limitations). 


\section{DCO FY98 Final Report, Balazs et al.}

\section{PLANNED SCOPE OF WORK}

The work originally proposed for FY1998 (October 1997 - January 1998, \$100K) was divided into two subtasks:

(1). Reaction Rate Data (October - December, 1997 \$70K).

(a) Certain transition metal ions $(\mathrm{Fe}, \mathrm{Cu}, \mathrm{Ni}, \mathrm{Ag}$, etc.) are known to accelerate the oxidation of organics by the peroxydisulfate ion by catalyzing its decomposition into one or two sulfate radical anions. Using diverse organic compounds as surrogate wastes, we will measure the integral rates of oxidation with and without catalysis. Six generic wastes will be examined on the $2 \mathrm{~L}$ reaction vessel level. For each waste, rates will be measured at $90{ }^{\circ} \mathrm{C}$ without catalysis and with 10, 30 and 100 ppm levels of catalysts. This will provide both an option for treating refractory organics at moderate temperatures as well as knowledge of maximum rates at higher temperatures for wastes naturally containing these catalysts.

(b) We will use the pilot scale facility to obtain time-resolved reaction data for oxidation of chlorinated materials without hydrolysis. This will provide a predictive capability for treating wastes with lower levels of hydrocarbons than those warranting the hydrolysis pretreatment. This task can be substituted for another experimental plan at the discretion of MWFA management. Results will be reported as an appendix to the FY1997 project.

\section{(2). Support of Commercialization Effort (October 1997 - January, 1998; \$30K).}

We have initiated collaborative efforts with Perma-Fix Environmental Services, Inc. (Atlanta, GA) to jointly develop the DCO process as an adjunct to their current waste treatment technology. PermaFix, Inc. is a $\$ 30 \mathrm{M} / \mathrm{yr}$ waste treatment company with about 10 facilities located across the United States. The company is dedicated to the treatment of mixed and hazardous wastes using the Permafix Process, which is a chemical/physical method for immobilizing inorganic waste components to meet waste leachability regulations. This process has been demonstrated on over 300,000 drums of hazardous waste material to date. We have met with PermaFix on three separate occasions to date, and it is believed that the described technology from LLNL fits well within the needs and scope of PermaFix' market plan. Both parties are currently exploring means with which to transfer this technology and demonstrate it on waste streams under consideration by PermaFix. Through modeling and point experimental efforts, we will speed the transfer of this technology, and this work will involve a proprietary approach to the treatment of undifferentiated wastes in an inert matrix such as soils, gravel, sand or clay.

Milestone: Issue final report addendum to FY1997 report: February 28, 1998

In addition, due to administrative issues, some of the work originally scheduled for FY97 was not completed until the end of October 1997. This work included a testing of the integrated bench scale system developed as part of scheduled FY97 work on chlorosolvent destruction in a surrogate sludge matrix. Carryover funds from FY97 were used to complete this work in October of FY98. The results of this work are reported in the FY97 DCO Final Report. [35] 


\section{CATALYST WORK}

Previous work on the effect of transition metal catalysts on the rate of oxidation of organic substrates by peroxydisulfate [18-20,29-34] focused primarily on the decomposition of the peroxydisulfate, and not on the mineralization of the organic. For the work detailed in this report, it was felt that a more realistic approach with regard to waste treatment by DCO was to measure the overall Destruction and Removal Efficiencies (DRE's) on a matrix of catalysts, temperatures, and organic substrates. In addition, most of the work was focused on $20-50{ }^{\circ} \mathrm{C}$ as this regime is closer to temperatures likely to be encountered when using DCO to treat waste under close to ambient conditions. No additional oxidant was added in most cases, except as noted, in order to more closely simulate a "one-pass" treatment approach.

Experiments were conducted at the laboratory scale (1.0 liter reactor), using acidified ( 0.1 $\left.\mathrm{M} \mathrm{H}_{2} \mathrm{SO}_{4}\right)$ solutions of $1.0 \mathrm{M}\left(\mathrm{NH}_{4}\right)_{2} \mathrm{~S}_{2} \mathrm{O}_{8}$. Catalyst ions were added in the form of the sulfate salts of the appropriate transition metal, except in the case of $\mathrm{Ag}$ which was by addition of the nitrate salt. Solutions were put into lightly stoppered $250 \mathrm{ml}$ glass flasks immersed in a water bath at the appropriate temperature. Four organic substrates were tested: ethylene glycol (Tables II-V), 1,3-dichloro-2-propanol (Tables VI, VII), tributyl phosphate (Table VIII), and the hydrolysis product of 1,1,1-trichloroethane (Table IX). [35] Initial organic loading was between 500 and $6000 \mathrm{ppm}$ total carbon, and the catalyst concentrations were varied between 1 and $1000 \mathrm{ppm}$ (with the exception of additional Fe tests at $5900 \mathrm{ppm}$ ). Additional oxidant was added after each period as noted. DRE's were measured by Total Carbon (TC) analysis on the solution. 


\section{DCO FY98 Final Report, Balazs et al.}

6

\section{A. Ethylene Glycol}

Results for ethylene glycol are shown in Tables II-V, and Figures 1-4.

Table II. (1800 ppm carbon loading, $50{ }^{\circ} \mathrm{C}$, three batches of oxidant). See also Figure 1.

\begin{tabular}{|c|c|c|c|}
\hline catalyst & DRE after 6 hrs & DRE after 12 hrs & DRE after 18 hrs \\
\hline none & 0 & 87 & 92 \\
\hline $10.2 \mathrm{ppm} \mathrm{Cu}$ & 0 & 90 & 92 \\
\hline $103 \mathrm{ppm} \mathrm{Cu}$ & 2 & 89 & 92 \\
\hline $9.6 \mathrm{ppm} \mathrm{Co}$ & 1 & 85 & 92 \\
\hline $105 \mathrm{ppm} \mathrm{Co}$ & 6 & 95 & 97 \\
\hline $1 \mathrm{ppm} \mathrm{Ag}$ & 2 & 79 & 88 \\
\hline $10 \mathrm{ppm} \mathrm{Ag}$ & 49 & 93 & 94 \\
\hline $104 \mathrm{ppm} \mathrm{Ag}$ & 99.9 & $99.9+$ & $99.9+$ \\
\hline $100 \mathrm{ppm} \mathrm{Fe}$ & 1 & 82 & 90 \\
\hline $4000 \mathrm{ppm} \mathrm{Fe} \mathrm{(mild} \mathrm{steel)}$ & 62 & 93 & 81 \\
\hline $99 \mathrm{ppm} \mathrm{Mn}$ & 58 & 77 & 72 \\
\hline $101 \mathrm{ppm} \mathrm{Ni}$ & 2 & 1 & 85 \\
\hline Pt wire & 0 & 73 & \\
\hline
\end{tabular}

Table III. (1800 ppm carbon loading, $35^{\circ} \mathrm{C}$, three batches of oxidant). See also Figure 2.

\begin{tabular}{|c|c|c|c|}
\hline catalyst & DRE after 6 hrs & DRE after 12 hrs & DRE after 18 hrs \\
\hline $102 \mathrm{ppm} \mathrm{Ag}$ & 98.8 & 99.4 & 99.8 \\
\hline $100 \mathrm{ppm} \mathrm{Co}$ & 1.6 & 13 & 14 \\
\hline $100 \mathrm{ppm} \mathrm{Fe}$ & 0.8 & 13 & 12 \\
\hline
\end{tabular}

Table IV. (1800 ppm carbon loading, $20^{\circ} \mathrm{C}$, three batches of oxidant). See also Figure 3.

\begin{tabular}{|c|c|c|c|}
\hline catalyst & DRE after 6 hrs & DRE after 12 hrs & DRE after 18 hrs \\
\hline $100 \mathrm{ppm} \mathrm{Ag}$ & 89.9 & 97.1 & 98.4 \\
\hline $101 \mathrm{ppm} \mathrm{Co}$ & 2.4 & 14 & 13 \\
\hline $100 \mathrm{ppm} \mathrm{Fe}$ & 5.5 & 15 & 14 \\
\hline
\end{tabular}

Table V. (1800 ppm carbon loading, $20^{\circ} \mathrm{C}$, single batch of oxidant, longer runs). See Figure 4.

\begin{tabular}{|c|c|c|}
\hline catalyst & DRE after $96 \mathrm{hrs}$ & DRE after 192 hrs \\
\hline none & 2.8 & 0.6 \\
\hline $1000 \mathrm{ppm} \mathrm{Cu}$ & 0 & 0 \\
\hline $1000 \mathrm{ppm} \mathrm{Co}$ & 5.0 & 7.8 \\
\hline $1000 \mathrm{ppm} \mathrm{Fe}$ & 4.4 & 2.2 \\
\hline $10000 \mathrm{ppm} \mathrm{Fe}$ & 44 & 82 \\
\hline
\end{tabular}


DCO FY98 Final Report, Balazs et al. 7

Figure 1. (1800 ppm carbon loading, $50{ }^{\circ} \mathrm{C}$, three batches of oxidant)

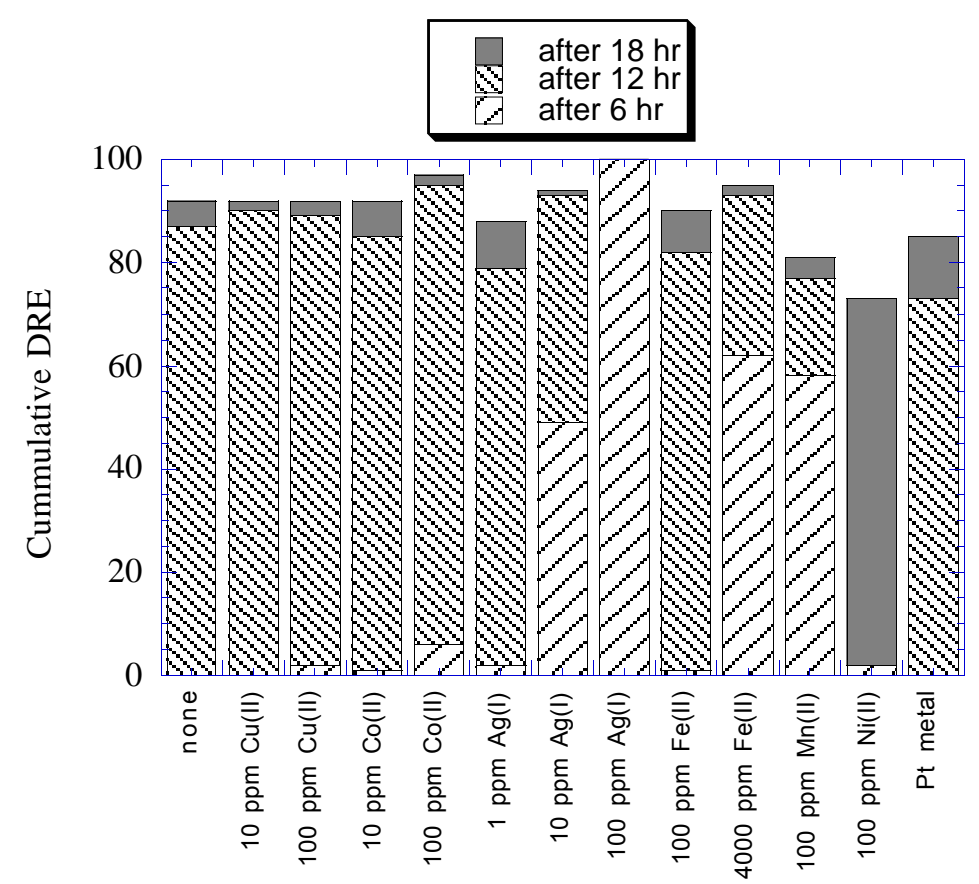

Figure 2. (1800 ppm carbon loading, $35^{\circ} \mathrm{C}$, three batches of oxidant)

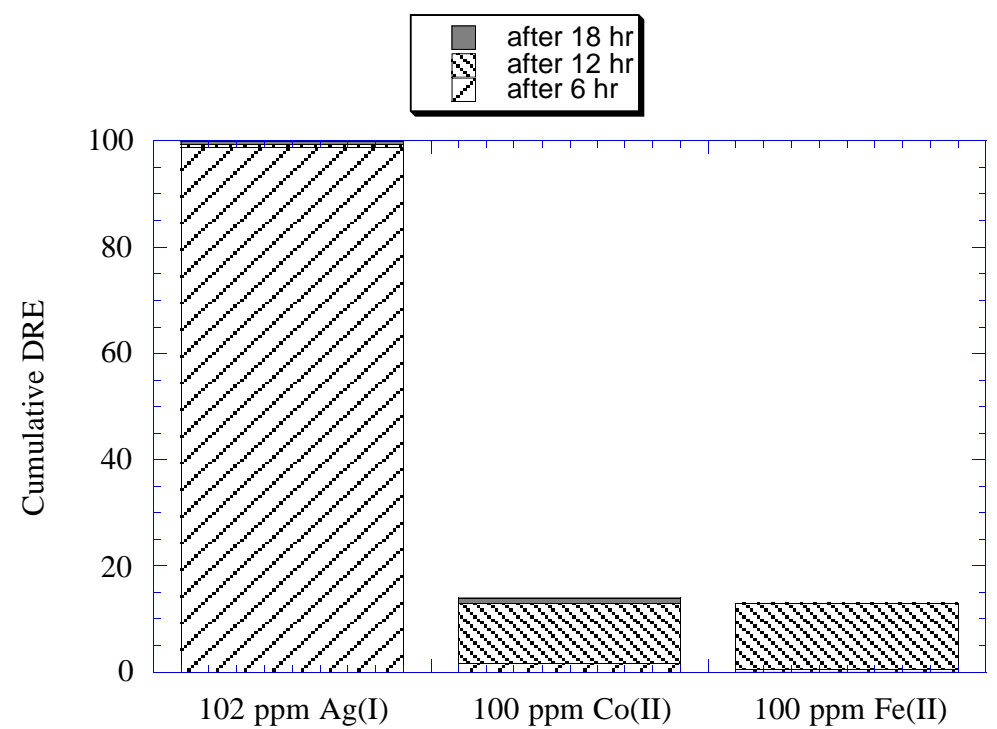




\section{DCO FY98 Final Report, Balazs et al. 8}

Figure 3. (1800 ppm carbon loading, $20^{\circ} \mathrm{C}$, three batches of oxidant)

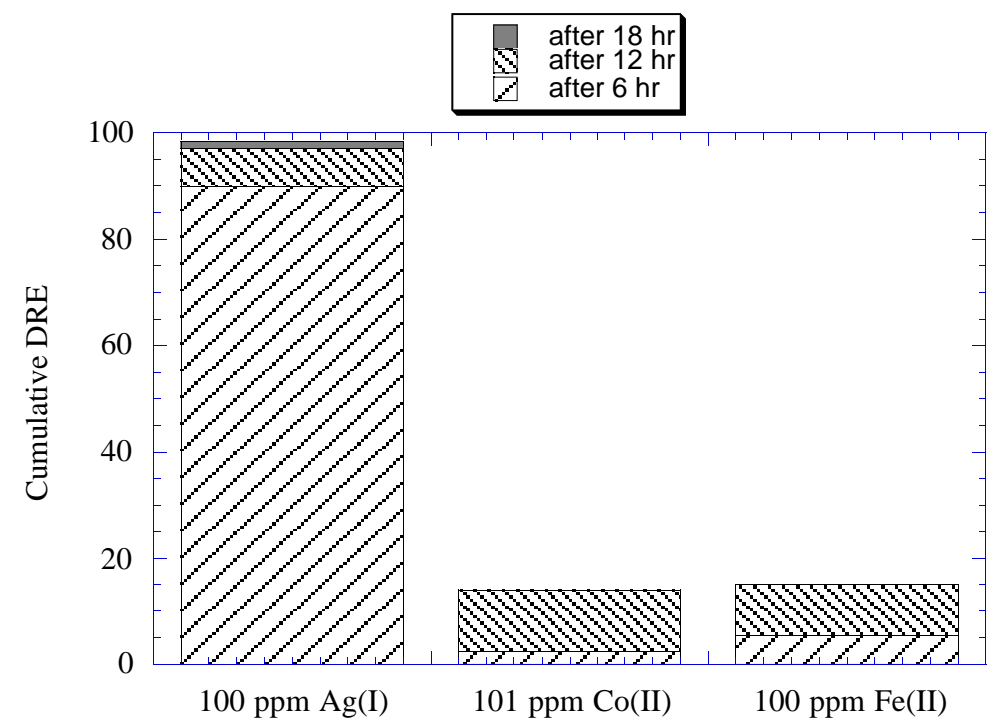

Figure 4. (1800 ppm carbon loading, $20{ }^{\circ} \mathrm{C}$, single batch of oxidant, longer runs)

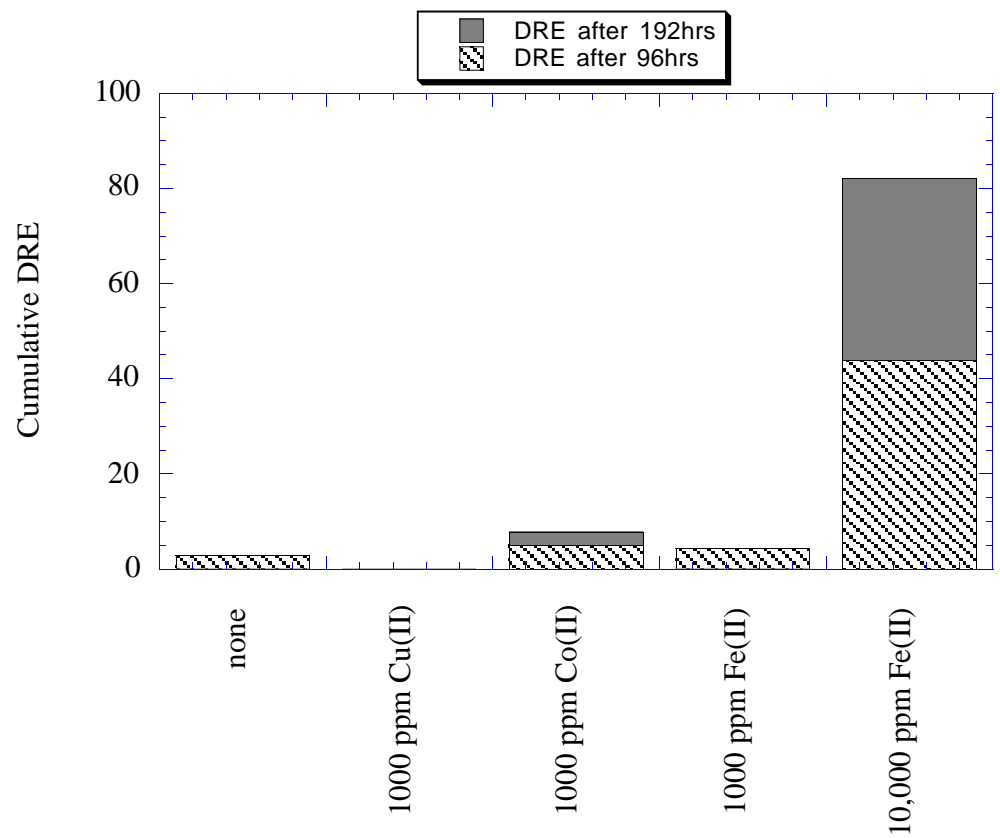




\section{DCO FY98 Final Report, Balazs et al.}

B. 1,3-dichloro-2-propanol

Results for 1,3-dichloro-2-propanol are shown in Tables VI-VII, and Figures 5,6.

Table VI. (1700 ppm organic loading, $50^{\circ} \mathrm{C}$, three batches of oxidant). See Figure 5.

\begin{tabular}{|c|c|c|c|}
\hline catalyst & DRE after $6 \mathrm{hrs}$ & DRE after $12 \mathrm{hrs}$ & DRE after $18 \mathrm{hrs}$ \\
\hline none & 6.5 & 29 & 50 \\
\hline $10.0 \mathrm{ppm} \mathrm{Cu}$ & 6.5 & 29 & 51 \\
\hline $102 \mathrm{ppm} \mathrm{Cu}$ & 4.9 & 29 & 50 \\
\hline $106 \mathrm{ppm} \mathrm{Co}$ & 11 & 35 & 66 \\
\hline $105 \mathrm{ppm} \mathrm{Ag}$ & 7.1 & 29 & 48 \\
\hline $4000 \mathrm{ppm} \mathrm{Fe} \mathrm{(mild} \mathrm{steel)}$ & 17 & 36 & 39 \\
\hline
\end{tabular}

Table VII. (1800 ppm organic loading, $20^{\circ} \mathrm{C}$, single batch of oxidant, longer times). See Fig. 6 .

\begin{tabular}{|c|c|c|}
\hline catalyst & DRE after $96 \mathrm{hrs}$ & DRE after $192 \mathrm{hrs}$ \\
\hline none & 0.6 & 2.2 \\
\hline $1000 \mathrm{ppm} \mathrm{Cu}$ & 3.9 & 2.8 \\
\hline $1000 \mathrm{ppm} \mathrm{Co}$ & 3.9 & 7.8 \\
\hline $1000 \mathrm{ppm} \mathrm{Fe}$ & 2.8 & 2.2 \\
\hline $10000 \mathrm{ppm} \mathrm{Fe}$ & 3.9 & 5.0 \\
\hline
\end{tabular}


DCO FY98 Final Report, Balazs et al.

10

Figure 5. (1700 ppm organic loading, $50{ }^{\circ} \mathrm{C}$, three batches of oxidant).

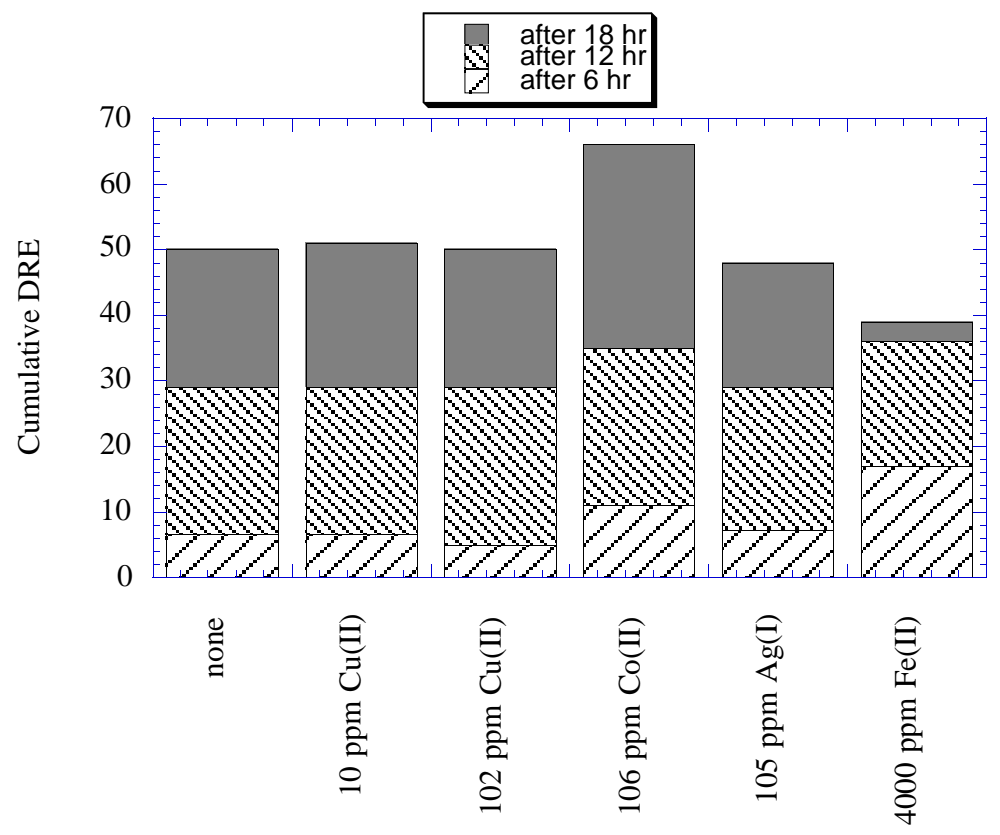

Figure 6. (1800 ppm organic loading, $20^{\circ} \mathrm{C}$, single batch of oxidant, longer times)

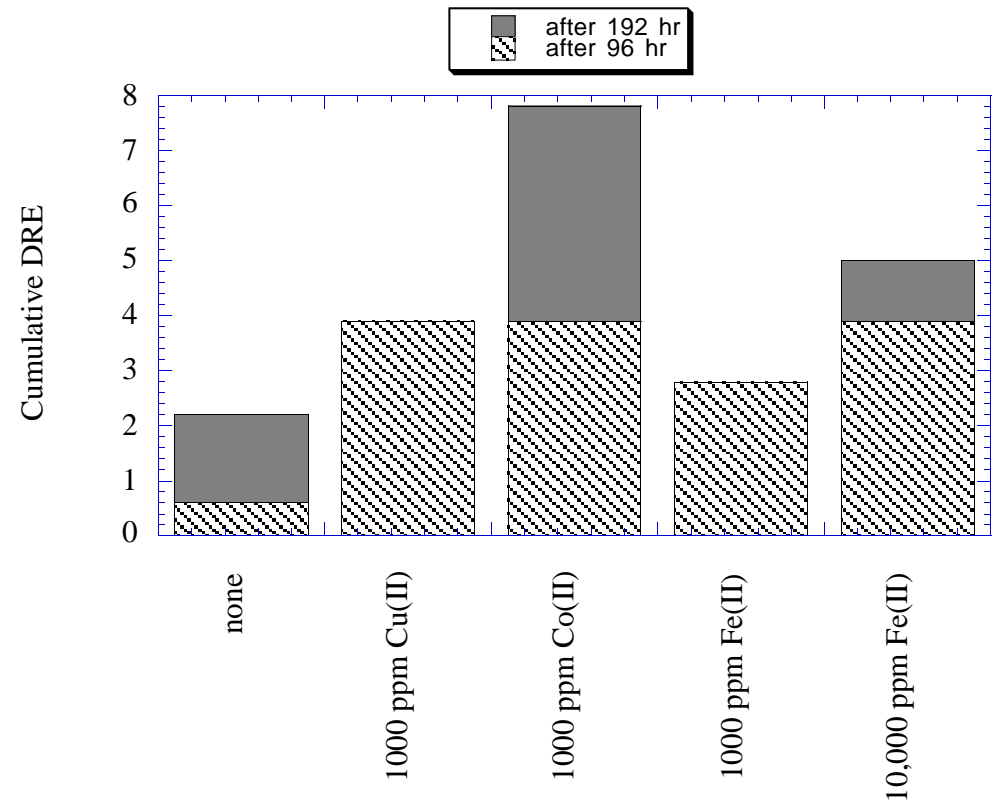




\section{DCO FY98 Final Report, Balazs et al.}

11

\section{Tributyl Phosphate}

Note: Tributyl phosphate is only partially soluble in water, and results with this organic substrate gave inconsistent results. The initial conditions of the experiments were such that the added level of organic was $1700 \mathrm{ppm}$ as carbon, but TOC results on this initial solution gave results of 200-300 ppm as carbon. Indeed, a second phase was observed on the walls of the reaction flasks. Although the results are presented below in Table VIII for tributyl phosphate, these data are judged to be invalid for the above reason.

Table VIII (1700 ppm organic loading, $50{ }^{\circ} \mathrm{C}$, single batch of oxidant)

\begin{tabular}{|c|c|c|c|}
\hline catalyst & ppm C after 6 hrs & ppm C after 12 hrs & ppm C after 18 hrs \\
\hline none & 299 & 253 & 240 \\
\hline $10.0 \mathrm{ppm} \mathrm{Cu}$ & 219 & 258 & 164 \\
\hline $102 \mathrm{ppm} \mathrm{Cu}$ & 237 & 269 & 250 \\
\hline $105 \mathrm{ppm} \mathrm{Co}$ & 334 & 208 & 239 \\
\hline $103 \mathrm{ppm} \mathrm{Ag}$ & 93.5 & 311 & 163 \\
\hline 4000 ppm Fe (mild steel) & 341 & 230 & 252 \\
\hline
\end{tabular}


DCO FY98 Final Report, Balazs et al.

12

D. Hydrolysis product of 1,1,1-trichloroethane

Table IX (4900 ppm organic loading, $20^{\circ} \mathrm{C}$, single batch of oxidant, longer times)

\begin{tabular}{|c|c|c|}
\hline catalyst & DRE after $72 \mathrm{hrs}$ & DRE after 144 hrs \\
\hline none & 2.7 & 3.7 \\
\hline $100 \mathrm{ppm} \mathrm{Fe}$ & 4.5 & 5.5 \\
\hline $100 \mathrm{ppm} \mathrm{Co}$ & 5.1 & 3.7 \\
\hline $100 \mathrm{ppm} \mathrm{Cu}$ & 4.1 & 5.9 \\
\hline
\end{tabular}




\section{E. Decomposition of Peroxydisulfate}

In order to assess the effect of several transition metal ions on the DCO system at normal operating temperatures, the reduction of peroxydisulfate and the mineralization of the organic were studied at $80{ }^{\circ} \mathrm{C}$. Measurements were made of both the instantaneous concentration of peroxydisulfate (by titration) and the conversion of organic to carbon dioxide (by on-line IR gas analysis). Ethylene glycol and the hydrolysis output of chlorosolvent hydrolysis were used as substrates; several typical transition metals were tested with each.

\section{Ethylene Glycol}

Figure 7 shows the decrease in peroxydisulfate concentration as a function of time during the oxidation of ethylene glycol (1400 ppm loading). Initial $\left[\mathrm{S}_{2} \mathrm{O}_{8}{ }^{2-}\right]$ is $1.0 \mathrm{M}$, in $0.1 \mathrm{M} \mathrm{H}_{2} \mathrm{SO}_{4}$. Each of the catalysts systems, except for $100 \mathrm{ppm}$ Fe(II), showed some catalytic activity for the decomposition of peroxydisulfate, with the silver system being the most pronounced.

Figure 7.

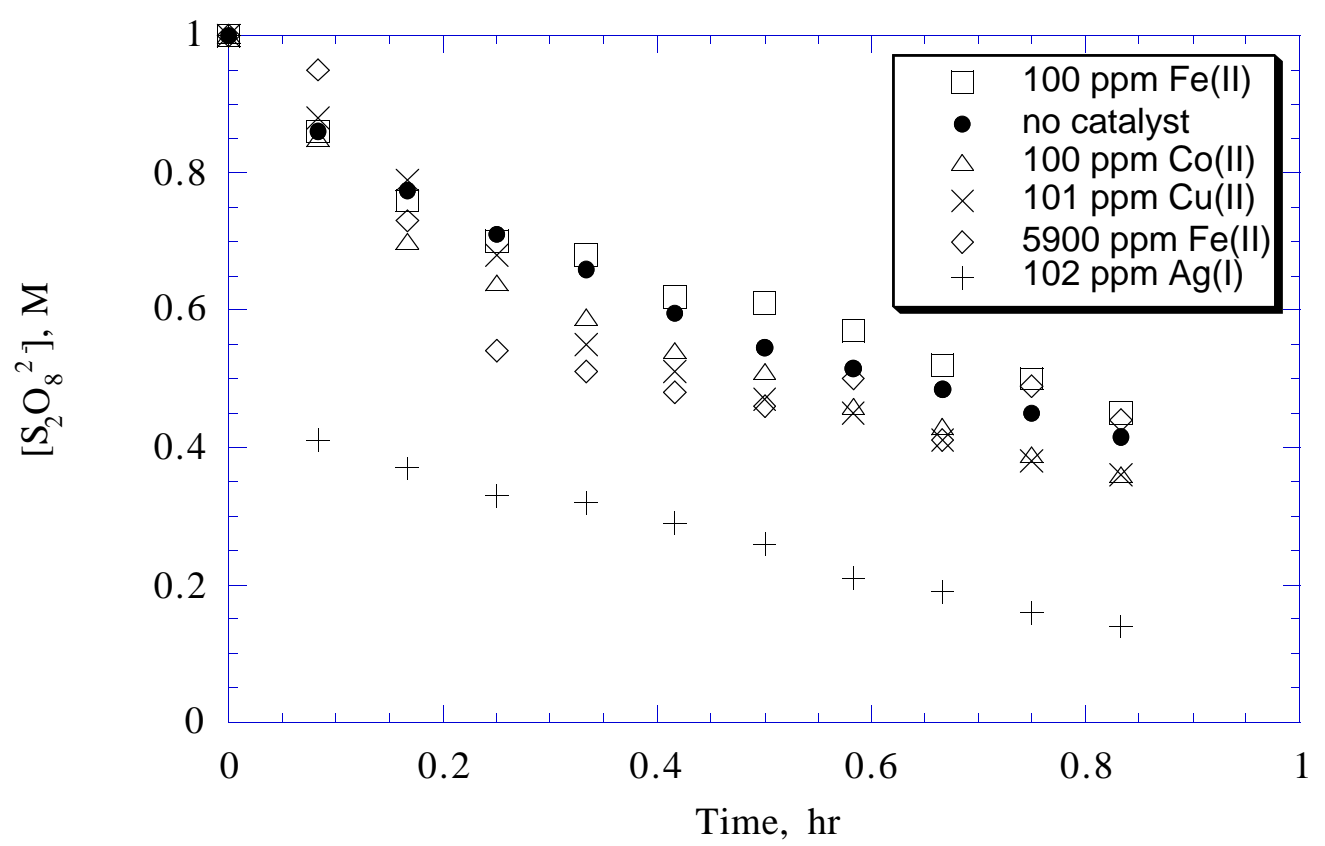


Figure 8 shows the output of carbon dioxide obtained during each of seven runs, with and without the catalysts as noted, during the oxidation of ethylene glycol at $80{ }^{\circ} \mathrm{C}$. The expected output based on the amount of ethylene glycol initially added was $420 \pm 20 \mathrm{ml} \mathrm{CO}$. All of the results fall within this range, but the silver system is noticeably different, both in terms of a higher $\mathrm{CO}_{2}$ output as well as a much steeper rise. Although the latter result is expected due to the catalytic activity, a reason for the former observation is not known.

Figure 8.

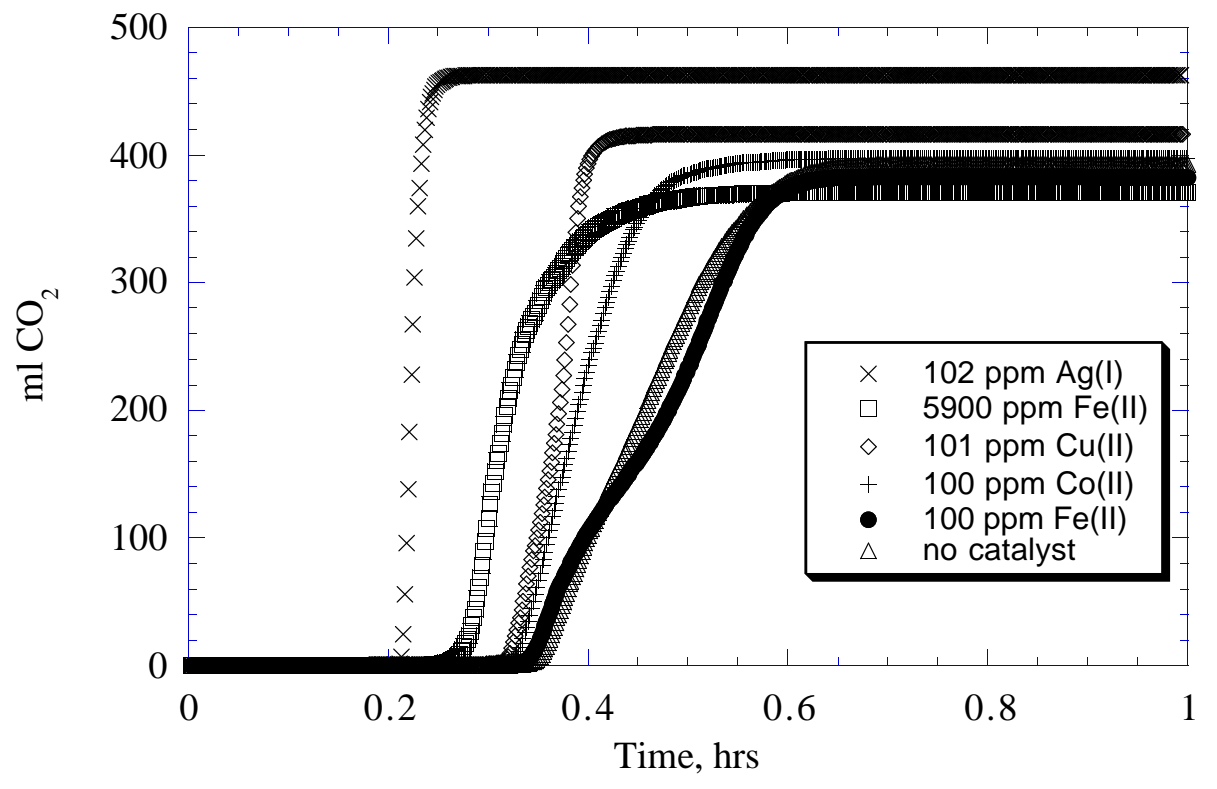


Product of Hydrolysis of 1,1,1-trichloroethane

Figure 9 shows the decrease in peroxydisulfate concentration as a function of time during the oxidation of hydrolyzed $1,1,1$-trichloroethane ( $3400 \mathrm{ppm}$ loading) at $80{ }^{\circ} \mathrm{C}$. Initial $\left[\mathrm{S}_{2} \mathrm{O}_{8}{ }^{2-}\right]$ is $1.0 \mathrm{M}$, in $0.1 \mathrm{M} \mathrm{H}_{2} \mathrm{SO}_{4}$. Again, these results are quantitatively similar to those obtained with ethylene glycol as the organic substrate, whereby all the catalysts showed varying activity with the exception of 100 ppm Fe(II).

Figure 9.

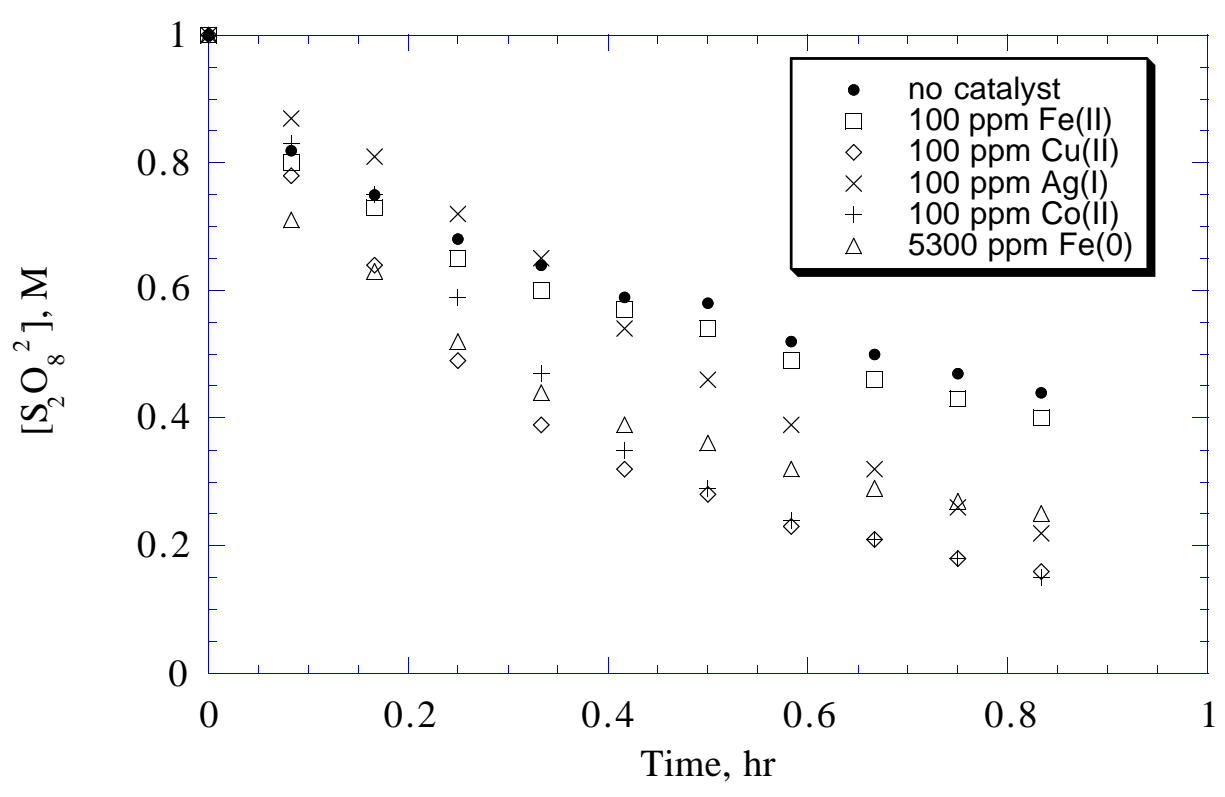


Figure 10 shows the output of carbon dioxide obtained during each of seven runs, with and without the catalysts as noted, during the oxidation of hydrolysis product at $80{ }^{\circ} \mathrm{C}$. Insufficient oxidant was intentionally added to completely oxidize the organic to carbon dioxide. The expected output based on the amount of ethylene glycol initially added was $420 \pm 20 \mathrm{ml} \mathrm{CO}$. All of the results fall within this range except for the cobalt and silver systems (the results were repeatable), but no explanation is available for this latter behavior.

Figure 10.

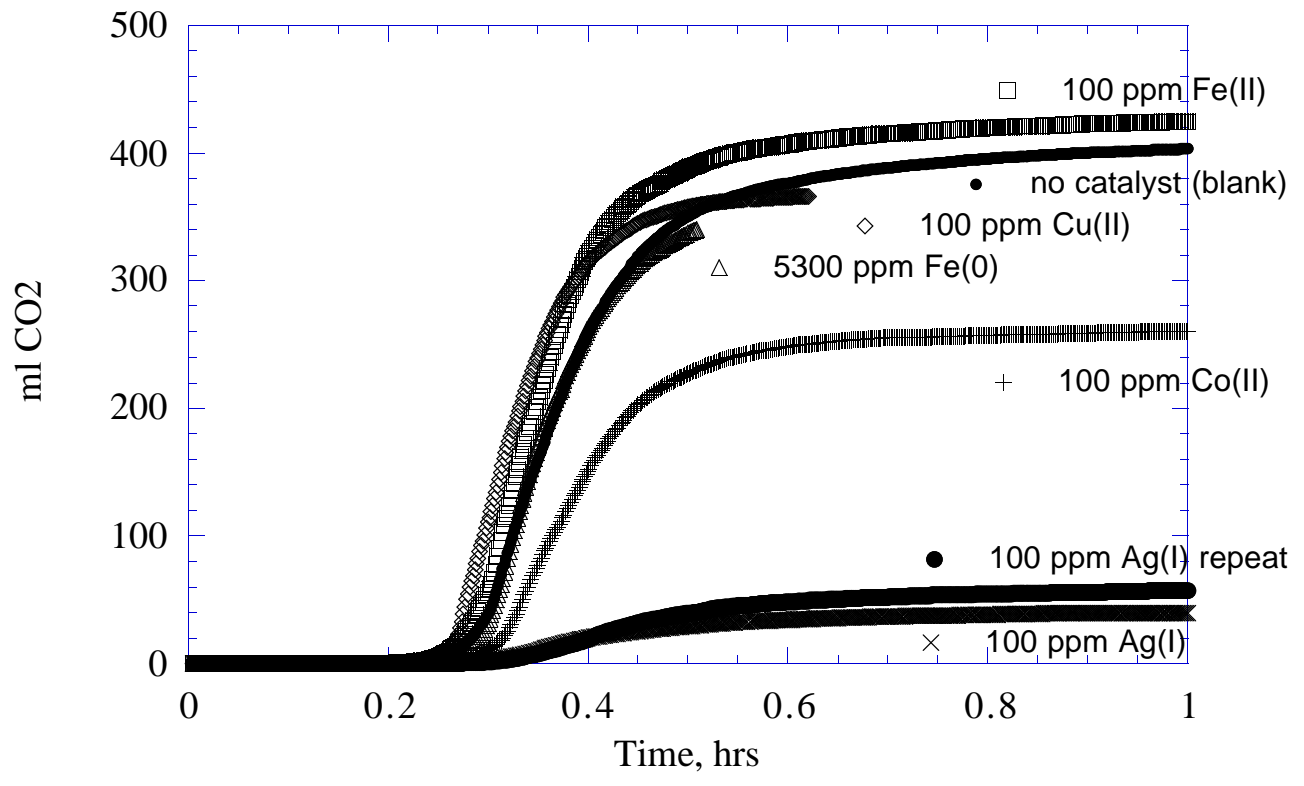




\section{DCO FY98 Final Report, Balazs et al.}

\section{F. Conclusions of Catalyst Tests}

All of the transition metals studied exhibited some effect on the rate of oxidation of the organic substrates by peroxydisulfate, although the magnitudes varied greatly. This is not surprising, as peroxydisulfate has a sufficient oxidation potential to oxidize all of the transition metals to their highest valent state, and the participation of these higher valence states in organic oxidations is well-known (36-39). It was generally the case that the transition metals which exhibited the most facile organic oxidation capability ( $\mathrm{Ag}(\mathrm{II}), \mathrm{Co}(\mathrm{III}), \mathrm{Fe}(\mathrm{III})$ ) also exhibited the most pronounced catalytic effect in these studies. Note that this order of catalytic effectiveness is surprisingly similar to the results obtained on Mediated Electrochemical Systems as described in references [36-39]. Although an all-encompassing maxim for the rate enhancements obtained with a specific catalyst is not possible, a general rule of thumb is that the effectiveness of the catalysts followed the general order $\mathrm{Ag}>>\mathrm{Co}>\mathrm{Cu}, \mathrm{Fe}>\mathrm{Pt}$. Individual results varied depending on the temperature regime, the organic substrate, and the matrix. This has been noted before in the literature. [18-20,29-34] The above results lead to the conclusion that catalysis of organic destruction by peroxydisulfate is merely due to the formation of another, favorably solvated transition metal cation with a high oxidation potential.

Complete destruction of the organics tested was achievable with silver as a catalyst, even at $20{ }^{\circ} \mathrm{C}$ in a relatively short time, and cobalt, iron or copper showed some enhancement although a much longer time was required. This result is backed by previous literature studies at discussed above. However, it was also noted in this current study that different organic substrates exhibited different behavior with respect to catalysis.

In all the cases studied, the enhancement of the organic destruction rate was a function of the catalyst concentration, and this is reflected in the literature as well (Eq. 4). Thus, higher rates of organic destruction can be achieved with higher catalyst concentrations. Due to the copious data available in the literature, a systematic reinvestigation of the order of the catalyst concentration on the rate equation was not attempted.

Although rate equations such as that shown in Eq. 4 would predict that destruction of organics might be faster with higher oxidant concentrations, the present work was not sufficiently detailed to either bolster or refute this statement. Additional oxidant made only a slight difference in DRE's, at least at close to ambient conditions. However, with higher organic loadings it may be necessary to periodically replenish the oxidant in waste treatment systems. See also the following section regarding oxidant concentration.

During catalyzed oxidations, there is an incubation period during which the carbon content of the solutions is unchanged from the initial value. This is presumably reflective of the fact that oxidation is occurring, but has not proceeded to the stage of evolving carbon dioxide from the solution and thus the carbon content of the solution remains unchanged from the original value. This incubation period was not noticed with silver, as oxidations with this catalyst proceeded much faster than the sampling timescales at the temperatures tested.

In waste systems containing chloride ion, or containing organic chlorine, silver ion is ineffective as a catalyst. $\mathrm{AgCl}$, being highly insoluble, immediately precipitates thus removing the active catalyst. Along these same lines, silver will be ineffective as a catalyst in systems where the $\mathrm{pH}$ is sufficiently high to result in the precipitation of silver hydroxide. In fact, this latter characteristic would presumably be extendable to all potential transition metal catalysts in systems at high $\mathrm{pH}$.

\section{G. Decomposition of Peroxydisulfate}

As shown in Figures 7 and 9, the concentration of peroxydisulfate decreases rapidly at 80 ${ }^{\circ} \mathrm{C}$ due to its reduction by organic and, to a lesser extent, water. All of added transition metals tested had some effect (with the exception of low concentrations of iron), and this effect was towards an acceleration of the peroxydisulfate decomposition rate. In the case of ethylene glycol as the added organic substrate (Figure 7), silver ion showed the highest perturbation, which is expected based on the fact that silver showed the highest catalytic effect in the destruction tests. The effect of silver was not nearly as pronounced in tests where chloride ion was present (Figure 
9). Based on results obtained with and without catalysts at $80^{\circ} \mathrm{C}$, peroxydisulfate does not appear to be a very aggressive oxidant at concentrations of less than about $0.3 \mathrm{M}$. Catalysts did not change this cutoff value appreciably. Thus, any DCO waste treatment system would have to keep the oxidant concentration greater than $0.5 \mathrm{M}$ for optimal efficiency.

During the experiments, it was noted that additional heat outputs were obtained at $80{ }^{\circ} \mathrm{C}$ with the catalysts, and the amount of extra heat correlated well with the acceleration in peroxydisulfate decomposition/organic destruction (Figures 7-10). As noted in the organic destruction tests detailed in the previous section, silver exhibited the most pronounced effect. As the oxidative destruction of organics is exothermic, any organic waste treatment system using peroxydisulfate must take into account the extra heat output encountered when transition metal ions (especially silver) are present.

It was noted that, when treating chlorinated organics, catalysts also affected the production of chlorine gas. However, this effect followed no logical pattern; in some cases the chlorine production (observed by watching the reactor offgas trap color) was immediate and quantitative and in other cases it was minimal. 


\section{TECHNOLOGY TRANSFER}

\section{A. Overview}

Lawrence Livermore National Laboratory has a several year commitment in the development of Direct Chemical Oxidation (DCO) for the treatment of the organic components of mixed and hazardous wastes. This technology has been developed to the point of limited pilot plant demonstrations at LLNL, and is now mature enough to test on expanded waste markets and ultimately commercialized.

Perma-Fix Environmental Services, Inc. is a $\$ 30 \mathrm{M} / \mathrm{yr}$. small business waste treatment company with about 10 facilities located across the United States. The company is dedicated to the treatment of mixed and hazardous wastes using the Perma-Fix Process, which is a chemical/physical method for immobilizing inorganic waste components to meet waste leachability and disposal regulations. This process has been demonstrated on over 300,000 drums of waste material to date. Currently, the material resulting from the Perma-Fix Process treatment of mixed wastes is subject to both RCRA and AEA/DOE regulatory controls, and must be disposed of accordingly. These regulatory restrictions add both cost and complexity to final disposal. An organic treatment technology such as DCO would render the final waste form as produced by Perma-Fix as non-hazardous, thus greatly enhancing Perma-Fix' marketability and economics.

Representatives of LLNL and Perma-Fix have initiated discussions towards the commercialization of the combination of DCO and the existing Perma-Fix Process, and it is believed that the described technology from LLNL fits well within the needs and scope of PermaFix' market plan. Both parties are currently exploring means with which to transfer the DCO technology and demonstrate it on mixed waste streams under consideration by Perma-Fix, or on mixed waste streams of interest to the DOE. Negotiations have been initiated for the implementation of a Cooperative Research and Development Agreement (CRADA) while both parties continue technical development work.

Although the incorporation of the DCO oxidative treatment technology by Perma-Fix could possibly be accomplished without involvement by LLNL, this path would require a considerable increase in the length of time to market, in the development cost, and in the potential for engineering errors. Because of the expertise that LLNL has acquired over the past three years of involvement with DCO (total DoE commitment to date is approximately $\$ 1.2$ million), Perma-Fix realized that all of the above development issues could be eliminated or at least minimized through collaboration with LLNL. Although Perma-Fix possessed the required regulatory and permitting experience to deal with the proposed mixed waste market, it lacked the "hands-on" experience of organic waste treatment. It was felt that the best approach was to build upon the expertise possessed by LLNL, and to complement the engineering capabilities of Perma-Fix with LLNL's prior data and experience.

\section{B. Perma-Fix Process/Treatment of Inorganic Residue}

Perma-Fix Environmental Services, Inc. is a small business in the area of waste treatment with its primary facility located in Gainesville, FL. Its primary focus is the treatment of hazardous or mixed wastes using The Perma-Fix Process, which is a solidification/stabilization method for inorganics. Perma-Fix has processed more than one million $\mathrm{ft}^{3}$ of mixed waste to date from all fifty states within the U.S., and customers include the government, industrial, medical and academic sectors. The company has all of the necessary permits and licensing to treat hazardous and mixed wastes, and is familiar with the regulatory issues associated with the introduction of new technologies.

Perma-Fix has developed a unique on-site treatment process that utilizes chemical treatment and solidification technology to transform inorganic containing hazardous wastes into nonhazardous materials. Wastes are converted into a chemically stable form through the use of chemical reactions that result in inherently more stable compounds that no longer represent an existing or potential threat to human health or the environment. In addition, non-hazardous liquids and sludges can also be treated to improve handling characteristics and to meet strict landfill 


\section{DCO FY98 Final Report, Balazs et al.}

20

disposal criteria. The EPA has determined that stabilization, which is the basis for the Perma-Fix Process, is the "Best Demonstrated Available Technology" for the pre-treatment and treatment of many listed and characteristic hazardous wastes. The Perma-Fix Process minimizes long term liability under RCRA, HSWA, CERCLA, and SARA.

The basis for the Perma-Fix Process is a multi-step procedure for permanent stabilization and solidification of the waste material. A sample of the waste is analyzed to develop a specific treatment formula, and a custom treatment formula for each waste stream is developed to remove hazardous constituents that cause disposal problems. After a custom treatment formula is developed, the Perma-Fix Process is brought to the location to treat the waste near the point of generation. The specially designed, self-contained treatment units can handle both drums and bulk materials. Treated waste is stored on-site until post treatment testing demonstrates that the waste meets treatment standards. This often allows the waste to be classified as "other industrial waste" that can be disposed of in a local special waste landfill rather than in a hazardous waste facility. Subsequently, Perma-Fix will prepare all documentation required under 40 CFR 268.7 (a)(2) and (a)(4) for state or regional review. Completed treatment of each batch is documented with analytical laboratory reports, manifests and a certificate.

The advantages of this process are as follows:

1) By utilizing the on-site Perma-Fix Process, treated hazardous waste disposal options may include non-hazardous disposal facilities,

2) Transportation-related liabilities will be eliminated by pre-transport stabilization since treated waste no longer poses a "spill" hazard,

3) The Perma-Fix Process can eliminate wastes from annual hazardous waste reporting requirements and helps achieve waste minimization targets required under federal regulations,

4) Short and long term liability is reduced and dollar savings are significant, including costs associated with taxes, treatment, transportation and disposal,

5) Perma-Fix provides a variety of services, including site assessments, storage tank services, site remediation, lab packing and full TSD services.

A wide variety of waste streams have been successfully treated using the Perma-Fix Process to render them non-hazardous. These include: blast media from paint removal, caustic cleaners, spent acid sludge, soil contaminated with heavy metals, chromium and cadmium plating sludge, lead chromate sludge, water fall paint booth sludge, glues and inks, non-hazardous and hazardous waste waters, and wastewater filter cake.

\section{FY97 Collaboration with Perma-Fix}

In FY97, Perma-Fix and Lawrence Livermore National Laboratories initiated a collaborative effort to develop a conceptual design for a process which would be capable of removal and destruction of the organics from a waste stream, followed by immobilization of the resultant liquid or sludge inorganic residue to meet land ban restrictions. A Personnel Exchange [40] was completed which involved the preliminary conceptual design as well as initial experiments on the organics destruction and final disposal of chlorosolvent-contaminated soils.

\section{FY98 Collaboration with Perma-Fix}

Lawrence Livermore is currently working with Perma-Fix on the development of a CRADA to full transfer this technology to the commercial sector. The potential market for the integration of DCO and Perma-Fix technologies is enormous, and is estimated to be several billion dollars within the DOE sector alone. Both parties have conducted negotiations with the owners of several waste streams to determine a suitable project (such as a treatability study) to measure the effectiveness of these technologies. The waste streams include ones at INEL (TSF-09), Hanford (RL-MW06) and Oak Ridge (waste ID \# L25-SSS-1). In addition, LLNL and Perma-Fix have collaborated on the development of two proposals in an effort to secure future funding. [41,42] Further identification of potential waste streams and funding opportunities is ongoing. 


\section{BUDGET \& ADMINISTRATIVE}

\section{Milestones}

Milestones Title

Catalyst Work \& Technology Transfer

Completion Date

February 1998

\section{Collaborators and Principal Performers}

PI: Bryan Balazs, Lawrence Livermore National Laboratory

co-PI: John F. Cooper, Lawrence Livermore National Laboratory

Technical Staff: Patricia R. Lewis, Lawrence Livermore National Laboratory

\section{Project/Variance Reporting:}

Progress Tracking System (PTS) input was provided on a monthly basis to highlight accomplishments and to report schedule and cost variance data. Recommended corrective actions were supplied when project cost and schedule variances exceeded a threshold of $+/-10 \%$ or $\$ 50$ $\mathrm{K}$, with a minimum threshold variance of $+/-\$ 10 \mathrm{~K}$.

\section{Cost Account Status}

All work completed and all accounts closed. See budget information below (Table X).

Table X. FY 1998 Projected \& Actual Spending

\begin{tabular}{|c|c|c|}
\hline Month & Projected, \$K & Actual, \$K \\
\hline October & $74^{*}$ & 41.2 \\
\hline November & 30 & 35.7 \\
\hline December & 30 & 35.6 \\
\hline January & 10 & 28.7 \\
\hline February & $25^{*}$ & 27.8 \\
\hline March & 0 & \\
\hline April & 0 & \\
\hline May & 0 & \\
\hline June & 0 & \\
\hline July & 0 & \\
\hline August & 0 & \\
\hline September & 0 & \\
\hline Total & $\mathbf{1 6 9 . 0}$ & $\mathbf{1 6 9 . 0}$ \\
\hline
\end{tabular}

*FY98 month of October had carryover from FY97 of $\$ 44 \mathrm{~K} ;$ \$25K additional added in February. 


\section{DCO FY98 Final Report, Balazs et al.}

\section{REFERENCES}

1. Bryan Balazs, John Cooper, Peter Hsu, Pat Lewis, Martyn Adamson, "Direct Chemical Oxidation: Destruction of chlorinated solvents by aqueous peroxydisulfate," poster presentation, SERDP Symposium, Washington, D.C., December 3-5, 1997.

2. Peter Hsu, John Cooper, Bryan Balazs, Pat Lewis, and Martyn Adamson, "Process Engineering of Direct Chemical Oxidation for the Treatment of Insoluble Chlorinated Solvents in Waste Streams," UCRL-JC-128142 abs., presented at AIChE Spring National Meeting, New Orleans, LA, March 8-12, 1998.

3. Bryan Balazs, John Cooper, Peter Hsu, Pat Lewis, Joe Penland, Larry Finnie, Martyn Adamson, "Integrated Direct Chemical Oxidation System for the Non-Thermal Destruction of Chlorosolvents," WM '98 Proceedings, Tucson, AZ, March 1-5, 1998, UCRL-JC-128131.

4. John F. Cooper, Francis Wang, Roger Krueger and Ken King, "Destruction of organic wastes with electrolytic regeneration of the oxidant," Proc. Sixth International Conference on Radioactive Waste Management and Environmental Remediation, Singapore, October 12-16 1997. UCRL-JC--121979 rev 2 July 1997.

5. John F. Cooper, G. Bryan Balazs, "Demonstration of Omnivorous Non-thermal Mixed Waste Treatment: Direct Chemical Oxidation of Organic Solids and Liquids using Peroxydisulfate," Final Report to Mixed Waste Focus Area, Oct. 1997.

6. J. Cooper, F. Wang, B. Balazs, R. Krueger, P. Lewis, T. Shell, J. Farmer, M. Adamson, "Destruction of organic wastes by ammonium peroxydisulfate," presented at AIChE Spring National Meeting (March 9-13, 1997), Houston, TX, UCRL-MI-126794.

7. Cooper, J. F., Wang, F., Balazs, G. B., Shell, T., Krueger, R., Lewis, P., Adamson, M., "Omnivorous Waste Destruction Process Using Uncatalyzed Peroxydisulfate Solutions," poster presentation at WM '97 conference, Tucson, Arizona, March 2-6, 1997, UCRL-MI126764.

8. John F. Cooper, F. Wang, J. Farmer, R. Foreman, T. Shell and K. King, "Direct Chemical Oxidation of Hazardous and Mixed Wastes" (Proc. of the Third Biennial Mixed Waste Symposium, American Society of Mechanical Engineers; Aug. 1995), Lawrence Livermore National Laboratory Report UCRL-JC-120141 March 28, 1995.

9. John F. Cooper, F. Wang, J. Farmer, M. Adamson, K. King and R. Krueger, "Direct Chemical Oxidation: Peroxydisulfate destruction of organic wastes," Proc. World Environmental Congress, International Conference and Trade Fair, Page 219, London Ontario, Sept. 17-22, 1995.

10. F. Wang, J. F. Cooper, J. Farmer, M. Adamson and T. Shell, "Destruction of ion exchange resins by wet oxidation and by direct chemical oxidation--a comparison study," Proc. World Environmental Congress, International Conference and Trade Fair, p. 206; London Ontario, Sept. 17-22, 1995.

11. John F. Cooper, Francis Wang, Roger Krueger, Ken King, Joseph C. Farmer, and Martyn Adamson, "Destruction of organic wastes by ammonium peroxydisulfate with electrolytic regeneration of the oxidant," LLNL Internal Report, September 1995. UCRL-121979 Rev 1, October 10, 1995.

12. John F. Cooper, Roger Krueger and Joseph C. Farmer, "Destruction of VX by aqueous-phase oxidation using peroxydisulfate: Direct chemical oxidation," (Proc. Workshop on Advances in Alternative Demilitarization Technologies, pp. 429-442, Reston VA September 2-7 1995, published by SAIC Aberdeen, MD)

13. John F. Cooper, Francis Wang, Roger Krueger, Ken King, Thomas Shell, Joseph C. Farmer, and Martyn Adamson, "Demonstration of omnivorous non-thermal mixed waste treatment: Direct chemical oxidation using peroxydisulfate," First Quarterly Report to Mixed Waste Focus Group, SF2-3-MW-35 October - December 1995; UCRL-ID-123193, February 1996.

14. John F. Cooper (with Joseph C. Farmer, Francis T. Wang, and Martyn G. Adamson, "Alternatives to Incineration," (Proc. ASME/EPRI Radwaste Workshop, New Orleans, LA, July 24-26 1996.) 


\section{DCO FY98 Final Report, Balazs et al.}

23

15. John F. Cooper, Francis Wang Thomas Shell, and Ken King, "Destruction of 2,4,6trinitrotoluene using ammonium peroxydisulfate," LLNL Report UCRL-ID-124585, July 1996.

16. W. M. Lattimer, "The oxidation states of the elements and their potentials in aqueous solutions," Prentice Hall , NY.

17. "Peroxides and Peroxy Compounds, Inorganic," Encyclopedia of Chemical Technology, V. 17, ed. Kirk Othmer.

18. D. A. House, "Kinetics and mechanism of oxidations by peroxydisulfate," Chem. Rev. 62, 185, (1961).

19. Francesco Minisci, Attillio Citterio and Claudio Giordano, "Electron-transfer processes: peroxydisulfate, a useful and versatile reagent in organic chemistry," Acc. Chem. Res. v. 16 27 (1983).

20. Gary R. Peyton, "The free-radical chemistry of persulfate-based total organic carbon analyzers," Marine Chemistry 41, 91-103 (1993).

21. Robert E. Huie and Carol L. Clifton, "Temperature Dependence of the Rate Constants for Reactions of the Sulfate Radical, SO4${ }^{-}$, with Anions," J. Phys. Chem., 94 (1990) 8561.

22. Neta, P., Huie, R.E., and Ross, A.B., "Rate constants for reaction of inorganic radicals in aqueous solution," J. Phys. Chem. Ref. Data, 17: 1027-1284, 1988.

23. I. M. Kolthoff and I. K. Miller, "The chemistry of persulfate. I. The kinetics and mechanism of the decomposition of the persulfate ion in aqueous medium," J. Am. Chem. Soc., p. 3055 July (1951).

24.P. D. Goulden and D. H. J. Anthony, "Kinetics of uncatalyzed peroxydisulfate oxidation of organic material in fresh water," Anal. Chem. 50(7) 953 (1978).

25. Model 700 TOC Total Organic Carbon Users Manual, (O.I. Analytical, Inc.; Graham road at Wellborn Rd. PO Box 2980; College Station TX 77841-2980).

26. Walter C. Schumb, Charles N. Satterfield, Ralph L. Wentworth, Hydrogen Peroxide, (Reinhold Publishing, Inc., New York, 1955).

27. Wolfgang Thiele and Hermann Matschiner, "Zur elektrosynthese von Wasserstoffperoxid und Peroxodisulfaten, Teil I. Wasserstoffperoxid und Peroxodischwefelsauer," Chem. Techn. v. 29(3) p. 148 (1977).

28. "Uses of Persulfate," FMC, Inc. Buffalo NY; 1951; 1960.

29. T. L. Allen, "The oxidation of Oxalate ion by Peroxydisulfate," J. Am. Chem. Soc, 73, 3589 (1951).

30. D. I. Ball, M. M. Crutchfield, J. O. Edwards, "The Mechanism of the Oxidation of 2-Propanol by Peroxydisulfate Ion,” J. Org. Chem, 25, 1599 (1960).

31. A. R. Gallapo and J. O. Edwards, "Kinetics and Mechanisms of the Spontaneous and MetalModified Oxidations of Ethanol by Peroxydisulfate Ion," J. Org. Chem. 36, 4089 (1971).

32. C. Walling and D. M. Camaioni, "Role of Silver (II) in Silver-Catalyzed Oxidations by Peroxydisulfate," J. Org. Chem., 43, 3266 (1978).

33. M. G. Ram Reddy, B. Sethuram and T. N. Rao, "Kinetics of Decomposition of Peroxydisulphate in the Presence of Mannitol Catalyzed by $\mathrm{Ag}^{+}$," Z. Phys. Chem., 256, 875 (1975).

34. V. N. Kislenko, A. A. Berlin, and N. V. Litovchenko, "Kinetics of Oxidation of Organic Substances by Persulfate in the Presence of Variable Valence Metal Ions," Kinet. Catal. (Trans. of Kinet. Katal.), 37, 767 (1996).

35. "Demonstration of Omnivorous Non-thermal Mixed Waste Treatment: Direct Chemical Oxidation of Organic Solids and Liquids using Peroxydisulfate," John F. Cooper, G. Bryan Balazs, Final Report to Mixed Waste Focus Area, Oct. 1997, UCRL-ID-129826.

36. Joseph Farmer, "Electrochemical Treatment of Mixed and Hazardous Wastes," (Chapter in "Environmental Oriented Electrochemistry," ed. Cesar A. C. Sequeira, Elsevier Science Publishers B.V., Amsterdam, The Netherlands; 1994). 
37.Zoher Chiba, Bruce Schumacher, Patricia Lewis and Laura Murguia, "Mediated electrochemical oxidation as an alternative to incineration for mixed wastes" (Proc. Waste Management 95 Symposium Tucson Arizona March 1 1995).

38. Joseph C. Farmer, Francis T. Wang, Patricia R. Lewis, and Leslie Summers, "Destruction of chlorinated organic by cobalt(III)-mediated electrochemical oxidation," J. Electrochem Soc. v. 139(11) 3025 (1992).

39. "Destruction of Hazardous and Mixed Wastes using Mediated Electrochemical Oxidation in a $\mathrm{Ag}(\mathrm{II}) / \mathrm{HNO}_{3}$ Bench Scale System," Balazs, B., Chiba, Z., Hsu, P., Lewis, P. Murguia, L., Adamson, Martyn, ICEM '97 Proceedings (Singapore, Oct. 12-16, 1997), UCRL-126754.

40. "Development of Direct Chemical Oxidation as a Complement to the Permafix Process," Personnel Exchange \# PE960003 between Lawrence Livermore National Laboratory and Perma-Fix Environmental Services, Inc., FY97 funding under U.S. DoD.

41. "A Low-Temperature Alternative for the Treatment of Mixed Wastes: Development of the Perma-Fix Process and Direct Chemical Oxidation as a pilot-plant facility," DoE unsolicited proposal with LLNL \& Perma-Fix, February 1998.

42. "A Non-Thermal Technology for the Treatment of Oil/Water Separator Sludge," SERDP Full Proposal, with LLNL \& Perma-Fix, to CPSON-99-03, March 1998. 